\title{
The Role of Sovereign Credit Ratings in Fiscal Discipline Meryem
}

Duygun * Huseyin Ozturk $\dagger \quad$ Mohamed Shaban $\ddagger$

\author{
February 19, 2016 \\ http://dx.doi.org/10.1016/j.ememar.2016.05.002 \\ http://www.sciencedirect.com/science/article/pii/S156601411630019X
}

\begin{abstract}
This paper investigates several aspects of the relationship between sovereign credit ratings and fiscal discipline. The analysis of over one thousand country-year observations for 93 countries during the 1999-2010 period reveals that a country's debt level is likely to increase with higher ratings, confirming the existence of pro-cyclicality and path dependence of ratings. In addition, the study finds no evidence to support the theory of Political Business Cycle, which implies that political ambitions may lead to fiscal worsening following a rating upgrade. The study findings further demonstrate that institutional quality is an important factor in the ratings-fiscal discipline nexus.
\end{abstract}


+Central Bank of the Republic of Turkey, huseyin.ozturk@tcmb.gov.tr ษUniversity of Leicester, ms272@le.ac.uk 


\section{Introduction}

Concerns about fiscal discipline became a central decision-making parameter of sovereign credit ratings (ratings) after the 2008 financial crisis. On 5 August 2011 Standard \& Poor's (S\&P) downgraded the US debt from AAA to AA+ for the first time in its rating history. Two years later, on 13 February 2013, the UK lost its Aaa rating, which it had had since the 1970s, as Moody's downgraded the UK economy by one notch, to Aa1. On 13 July 2012, Italy's rating fell by two notches (from A3 to Baa2). Japan's rating was threatened several times. Recently in July 2015, Fitch warned Japan against loss of fiscal discipline that could harm the country's economy by putting upward pressure on bond yields.

Vigilance of debt dynamics has also become more apparent in emerging market countries. In September 2015, Fitch's country report stated that the main drivers for affirming Turkey's rating were the government's strong fiscal discipline which was maintained through the elections and commitment to this discipline. In September 2015, S\&P also praised Mexico for its "Fiscal Discipline Law", which addresses the agency's key concerns. S\&P regards the law as successful because of its potential for maintaining sustainable debt levels.

Fiscal discipline in a monetary union can be even more challenging, while fiscal discipline in a monetary union without a central fiscal authority is very hard to achieve. The latest experience in the EU shows that debt sustainability issues in one member country can have significant impacts on other members due to the financial linkages arising from a single monetary policy and common currency. Although it has direct distorting effects, fiscal discipline in developed countries has not been a major concern for their ratings until the cascading crisis in the EU. Balassone et al. (2006) argue that ratings did not seem to substantially penalize fiscal profligacy in developed countries before the outbreak of the 2008 crisis. The literature on the determinants of ratings of emerging market countries is not in full agreement as to whether there is a substantial association between fiscal variables and ratings (Kumar and Ter-Minassian, 2007). The lack of adequate evidence on debt levels in explaining sovereign creditworthiness was also discerned by Celasun and Harms (2011) who emphasize that external debt figures are among the usual suspects when it comes to explaining sovereign risk, but academic endeavours to further understanding of the impact of debt level on sovereign creditworthiness are rather limited. 
This study investigates the impact of ratings and rating changes on fiscal discipline in the context of two complementary discussions on the understanding of the ratings-fiscal discipline nexus. The first one is the pro-cyclicality and path dependence of ratings with which we explore whether higher ratings create incentives to accumulate higher debt. The pro-cyclicality and path dependence of ratings suggest that ratings are closely associated with business cycles and rating history. The idea behind pro-cyclicality is that credit rating agencies (CRAs) might be overly optimistic in their rating assessment when the economy performs well (Ferri et al., 1999; Dimitrakopoulos and Kolossiatis, 2015). In a similar vein, path dependence simply means that ratings do not change considerably even if the country's fundamentals suggest it (Bangia et al., 2002; Dimitrakopoulos and Kolossiatis, 2015). Pro-cyclicality and path dependence of ratings create huge room for debt accumulation for high-rated countries, since an event risk that will drastically shatter their ratings is very low. The second discussion is the theory of Political Business Cycles (PBC), which, following from the seminal papers of Nordhaus (1975) and Hibbs (1986), models government investment behaviour when governments are constrained by their political objectives. We analyse how fiscal policies respond to rating changes under the theory of PBC which imply that fiscal and economic policies are closely affected by political motivation. We expect that opportunistic governments will increase their borrowing in an optimistic environment created by a rating upgrade.

Ratings issued by CRAs play a critical role in determining the cost and availability of capital to countries. Since the investment decisions of international investors are based on comparative assessments in the same asset class, ratings juxtapose each country based on its willingness and capacity to pay. It is well known that CRAs rigorously monitor countries' fiscal discipline. The rationale suggests that countries that have low levels of debt and fewer refinancing needs tend to get higher ratings. However, we still do not know the nature of the relationship between ratings and sovereign indebtedness (Celasun and Harms, 2011). Although the relationship between fiscal discipline and ratings has a direct impact on the probability of sovereign debt default, it has not attracted the research interest it deserves (Ferri et al., 1999; Celasun and Harms, 2011). A number of studies have focussed on the sources of persistence of ratings (including path dependence), pro- cyclicality and serial correlation (see e.g. Dimitrakopoulos and Kolossiatis, 2015), but how these factors affect sovereign borrowing has not been studied.

Opaqueness also surrounds the question of whether rating changes alter borrowing motivation 
opportunistically. The disciplining role of ratings on fiscal discipline has been studied through the lens of PBC theory around election times (Hanusch and Vaaler, 2013; Block and Vaaler, 2004) but these studies do not provide any evidence in general on how rating changes affect borrowing propensity.

This study aims to address these questions. We extend our research agenda by incorporating the level of "development" in our research questions. Whilst many institutional differences have been pointed out as key determinants for fiscal discipline and the rating decision, the question of how the relationship between ratings and fiscal discipline differs according to level of development remains unanswered.

The empirical analysis of over one thousand country-year observations for 93 countries during the 1999-2010 period largely supports our conceptual framework and related predictions. Specifically, we find that countries' debt levels are likely to increase with higher ratings, thus confirming the existence of pro-cyclicality and path dependence in ratings. However, we find no evidence to support the PBC theory. The findings suggest that governments do not exploit the supportive upgrade environment to borrow more, but show that this holds true only for the governments in developing countries. The results further demonstrate that governments with high institutional quality perform better in terms of fiscal discipline following a rating upgrade.

The paper contributes to the literature in at least three ways. First, we examine how procyclicality and path dependence of ratings can impact government debt dynamics. Although the drawbacks related to pro-cyclicality and path dependence of ratings have been debated from many perspectives, the implications of these problematic issues are fairly scarce. Second, we explore whether governments take advantage of their high ratings and further exploit the opportunities created by rating upgrades. In particular, we are motivated by the theory of $\mathrm{PBC}$, which posits that politicians often act in line with their opportunistic objectives. The opportunity to find cheaper and more abundant capital is expected to entice politicians to borrow more. Finally, we test for the effects of the rating changes in developed and developing countries separately, where there are considerable discrepancies in the quality of institutions. The results will be essential to determine whether governments' responses to rating changes are different in these two country groups.

The remainder of this paper is organized as follows: Section 2 briefly summarizes the theoretical discussion on pro-cyclicality and path dependence of ratings and the theory of PBC. Section 3 
presents the data from 93 countries with cross-country comparisons and a brief discussion about the methods used. Section 4 reports and discusses the main findings and implications, and Section 5 concludes.

\section{Theoretical Debates and Hypotheses}

\subsection{Theoretical Debates}

A review of the debates on the role of CRAs in the current financial system will set the scene for the specific implications of this study. It is widely known that the regulations governing the current financial architecture, in place since the beginning of the nineties, afford due importance to the credit risk of financial assets and entities. Credit ratings are the main pillar of credit risk measurement in financial institutions essentially because the regulations are ratings-based. Although certain regulations are in place to ensure that the vitality of credit ratings remains fairly high, the credit rating industry is dominated by three big agencies (S\&P, Moody's and Fitch) which operate with an issuer-pays model. The market structure of the industry and its business model have attracted significant criticism of credit rating accuracy.

Among many issues of concern regarding ratings and CRAs, this paper focuses on the procyclicality and path dependence of ratings. One of the fundamental criticisms of CRA ratings is that, contrary to expectations that ratings should act as an early warning system, CRAs tend to over-rate in good times and be over-cautious in bad times (Pagano and Volpin, 2010; Eijffinger, 2012). The lack of proper signalling and inaccurate assessment of credit risk has prompted fierce debate among players in the global financial system. Several regulatory changes have been introduced since the 2008 financial crisis, although it is hard to say that the new regulatory regime has completely alleviated the concerns about ratings. The gradual development of countries' fundamentals suggests that ratings are highly dependent on past ratings. The belief that CRAs do not upgrade countries even if they demonstrate dramatic improvements in their fundamentals does not motivate policymakers to take timely action. On the other hand, the belief that CRAs do not downgrade enough even in cases where high-rated countries show significant deterioration in their credentials lead to reckless behaviour among policymakers. 


\subsection{Hypotheses}

In this research, we propose three hypotheses to examine the relationship between fiscal discipline and ratings.

\subsubsection{Fiscal Discipline and Ratings}

We first examine the relationship between ratings and fiscal indicators. Pro-cyclicality and path dependence of ratings can be potential sources of misalignment in ratings. Ratings are defined as being pro-cyclical when CRAs assign higher ratings to countries than their macroeconomic fundamentals would justify during "bad times" and shy away from downgrading even if their fundamentals suggest they should do so during "good times". A clear example of pro-cyclicality of ratings occurred when the ratings of major EU countries were sharply downgraded during the EU debt crisis (G"artner et al., 2011; Eijffinger, 2012; Paudyn, 2013). The fiscal indicators of these countries had already been alarming in the run-up to the crisis. However, rather than responding to fiscal deterioration in a timely and gradual way as CRAs are supposed to, downgradings were both tardy and acute.

We argue that the pro-cyclicality and path dependence of ratings create more borrowing incentives for high-rated countries since the lower sensitivity of ratings to debt levels creates a false impression that their ratings will remain unchanged. Therefore, we expect a significant association between ratings and sovereign borrowing. As an initial exercise, we test the implication of the procyclicality and path dependence of ratings on fiscal indicators. Since high-rated countries can find cheaper and more plentiful funding opportunities, these countries' fiscal indicators are generally expected to be worse than lower rated countries. The expectation that their ratings will hardly change feeds this anomaly (Paudyn, 2013).

Hypothesis 1: Fiscal indicators are negatively associated with ratings.

Over-reliance of debt markets on credit ratings is the main reason for the cheap funding and high rating relationship. See Eijffinger (2012), Pagano and Volpin (2010), White (2010), Ozturk (2015) and Paudyn (2013) for an excellent discussion. 


\subsubsection{Political Opportunism and Rating Changes}

The other fundamental research proposition in this study is that, based on the considerations linked to the theory of $\mathrm{PBC}$, opportunism may play a significant role in politicians' borrowing propensity in the context of the positive environment created by a rating upgrade. The main assumption in the traditional theory of $\mathrm{PBC}$ is that politicians, whose preference is to stay in power, are opportunistic whereas voters are short-sighted meaning that they tend to vote for the incumbent if the conditions before the election are beneficial to them (see e.g. Nordhaus, 1975; Hibbs, 1986; Hanusch and Vaaler, 2013; Block and Vaaler, 2004). The theory hypothesizes that politicians are always faced with a trade-off between political and economic objectives. A vigilant politician who seeks long-term economic benefits prefers to maintain fiscal discipline and even improve it after a rating upgrade. In contrast, an opportunistic politician takes advantage of the benefits created by a rating upgrade and ignores the long-term benefits of sustained fiscal discipline. Since the benefits from a rating upgrade can take longer to materialize than the benefits of an expansionary fiscal policy, an opportunist politician would opt to over-borrow in order to guarantee his or her seat in the next elections.

There is a stream of literature on politicians' opportunistic behaviour. Vaaler et al. (2006) contend that the issue is generally discussed in the context of developed rather than developing countries. These authors also argue that while evidence of opportunistic politicians in industrialized countries is mixed, empirical studies on developing countries mainly confirm the proposal that politicians follow their political objectives. Relevant studies include Schuknecht (1996), Berger and Woitek (1997) Block (2002), Akhmedov and Zhuravskaya (2004), and Block and Vaaler (2004), Sakurai and Menezes-Filho (2008), Klein and Sakurai (2015), Peters (2010).

Specifically, Schuknecht (1996) examined fiscal policies in a sample of 35 developing countries between 1970 and 1992. His main finding suggests that while electoral cycle has no significant impact on real output, governments in these countries seem to align government expenditures with elections. This finding is significant in more open countries where the trade share of GDP exceeds $50 \%$. The relationship between ratings and their determinants has been widely examined following the innovative studies of Cantor and Packer (1995) and Cantor and Packer (1996). Among many others, Afonso and Gomes (2011), Erdem and Varli (2014), Gültekin-Karakass et al. (2011) studied 
the determinants of ratings and found that the impact of fiscal balance on rating assessments is significant. All these authors conclude that CRAs attach considerable importance to fiscal balance meaning that the deterioration in fiscal balance is likely to trigger rating downgrades. However, studies have not to date examined how governments' behaviour changes after a rating action is taken. This scarcity in the literature motivates us to examine the impact of rating changes on fiscal discipline.

The research proposition related to the theory of PBC is that the opportunities created by rating upgrades play a significant role in governments' fiscal policies. With the incentives to borrow more and more cheaply in a period of positive sentiment following a rating upgrade, governments might find it rational to implement expansionary fiscal policies to guarantee their next term in office. Although such policies risk triggering future rating downgrades, this is likely to occur in the distant future, by which time the incumbents might already have been re-elected.

Hypothesis 2: Rating upgrades are likely to be associated with the deterioration of fiscal discipline.

\subsubsection{Institutions and Rating-Fiscal Discipline Nexus}

According to most of the models surveyed in Panizza et al. (2009), countries issue debt in order

to transfer income from bad times to good times for consumption smoothing purposes. The counter-cyclicality of sovereign borrowing suggested by these models is not supported by empirical evidence however (Yeyati, 2009; Gavin and Perotti, 1997). The anecdotal evidence suggests that the pro-cyclicality of borrowing is mainly driven by sovereign authorities' tendency to borrow whenever conditions allow (Panizza et al., 2009). Two constraints emerge limiting the tendency to borrow. The first is related to sovereigns' ability to borrow. If the global environment is an obstacle to issuing debt, sovereigns' ability to borrow can be significantly jeopardized. If the global economic cycle is favourable for borrowing, then legal barriers emerge. Sovereign credibility (ratings) is one of the basic barriers (conditions) to borrowing at lower costs. The second constraint that disciplines the borrowing tendency is associated with the quality of institutions. In countries where institutional capacity is strong enough to control politicians' actions, authorities are circumvented by legal enforcements that penalize reckless borrowing.

We have credible reasons to differentiate countries according to their level of "development" to 
examine the rating-fiscal discipline nexus. Ratings often respond to sovereign credibility with a considerable lag and with marginal rating changes, leading to a certain inertia in ratings. Inertia in ratings encourages developed countries to accumulate larger amounts of debt since the degree of inertia is larger in developed countries (Mulder and Monfort, 2000; Dimitrakopoulos and Kolossiatis, 2015). However, this does not prompt CRAs to be more cautious, as stated in Fitch Ratings (2012), since developed countries can arguably tolerate higher debt burden because of their resilience to economic shocks. Developing countries, on the other hand, have less opportunity to borrow due to their lower ratings. Since rating changes are more frequent and can be higher notch changes, they face the obstacle of stronger credit constraints when they want to borrow.

Countries can also be differentiated by their level of "development" to classify their fiscal response to rating changes. This separation finds support from institutional differences between developed and developing countries. It is reasonable to postulate that lower institutional quality in a country implies lower transparency, accountability and rule of law. Authorities in countries of lower institutional quality are more likely to exploit a rating upgrade since politicians would be under less threat of legal enforcement or public pressure. Robust institutions in developed countries, on the other hand, hinder selfish borrowing. Opportunist politicians who tend to overborrow would be subject to closer institutional scrutiny and harsh public criticism.

We argue that the fiscal discipline and ratings relationships hypothesized in Hypothesis 1 and Hypothesis 2 are structurally different in developed and developing countries. Politicians in developing countries have a more relaxed attitude to exploiting the opportunities created by ratings and rating changes.

Hypothesis 3: The impact of rating and rating changes on fiscal discipline is more visible in developing countries.

\section{Data and Methodology}

\subsection{Data}

In this paper, the use of fiscal discipline refers to the amount of debt burden placed on governments. In practice, governments are expected to repay their current expenditures with their current revenues. If current revenues fall behind current expenditures, the resulting shortfall can 
be met either by running down state assets or from borrowing. The borrowed money is treated as fiscal deficit, which can bring citizens a certain amount of relaxation and increase political support for the current government. However, fiscal deficits lead to tax burdens for future generations and complicate future governments' ability to pay. Fiscal indicators are among the most important indicators examined by CRA analysts. The ability of governments to extract revenues from taxpayers and users of government services, the elasticity of government revenues with respect to the average growth rates, and the rigidities in government expenditures are the key factors that determine countries credit ratings. It is widely believed that a mounting debt burden in a country creates repayment difficulties that in turn motivate CRAs to downgrade the country's rating.

We believe that central government debt figures may not show the actual degree of indebtedness of a country since they may not show off-budget expenditures. Due to these considerations we also examine other forms of government expenditure. "General government" is one of the most widely used categorical classifications to obtain a joint baseline that can be used to assess a country's public finance credentials. We focus on measures at the general government level, which is the sum of central and local governments, including social security expenditures and other extra-budgetary funds engaged in non-commercial activities. General government measures, however, do not take into account inter-governmental transactions.

We consider that general government fiscal indicators, which are mostly associated with macroeconomic stability and economic growth, better capture a country's fiscal discipline. In addition, general government is the most useful cross-country comparator because the bodies responsible for raising taxes and planning expenditure may differ between countries. All segments of government, however, ultimately rely on the same population to pay taxes, and sovereignty (of countries) is expected to have the strongest influence on the distribution of public sector expenditures between different tiers of government.

In this paper, we examine fiscal discipline on general government debt stock and general government fiscal balance. To eliminate the impact of the scale of the economies on fiscal figures, we normalize the measures by the size of the economies. We use Moody's rating categorization to represent all rating symbols. Although the alpha-numeric representation differs from one CRA to another, the rating categories are identical.

Moody's classification has twenty categories based on a country's degree of perceived creditwor- 
thiness. Credit risk increases from category Aaa (least risk) to category Ca (highest risk). CRAs establish a threshold to rate groups as "investment grade" and therefore safe for investment. A CRA's consideration below this threshold is risky. The investment grade group includes the categories Aa1, Aa2, Aa3, A1, A2, A3, Baa1, Baa2, Baa3; the speculative grade group comprises categories Ba1, Ba2, Ba3, B1, B2, B3, Caa1, Caa2 and Caa3. The data used in this study includes 106 countries for the 1999-2010 period. We did not include Caa2, Caa3, and Ca rated countries in our analysis because their country fundamentals are very fragile and would introduce distortion. These countries are Argentina, Belize, Cuba, Ecuador, Jamaica, Nicaragua, Pakistan, Paraguay, Ukraine, and Venezuela. We also omitted Cayman Islands, Bermuda, and Bahamas since many of the explanatory variables used in the regressions were not available for these countries.

To investigate the impact of rating and rating changes on fiscal discipline, we also use several controls to represent countries' economic structure and performance. Table 1 presents the variables, their descriptions and sources. These variables include GDP percentage change, inflation, ratio of domestic saving to GDP, and an openness indicator. We also include World Governance Indicators to quantify the quality of institutions in a country (Kaufmann et al., 1999). These indicators are individual indices that take values between -2.5 and 2.5 where higher values indicate better institutional quality.

\section{-INSERT TABLE 1 AROUND HERE-}

In an effort to better assess the rating-fiscal discipline nexus at different levels of development, the data is divided into two sub-samples: developed and developing countries. We use the World Bank country classification to determine countries' level of development. According to this classification, countries can be broadly grouped into five categories: high income: OECD, high income: non-OECD, low income, lower middle income, and upper middle income. We group high income: $O E C D$ and high income: non-OECD countries in the "developed country" category and low income, lower middle income, and upper middle income countries in the "developing country" category. The definition of "development" based on income level gives us an opportunity to examine possible differences in fiscal behaviour between high-rated and low-rated countries. We know that developed countries have significantly higher ratings than developing countries. Table 2 gives the distribution of countries by their income level, which is used to proxy development level. 


\subsection{Methodology}

Two main arguments will be tested in this paper. First, we test whether pro-cyclicality and path-dependence of ratings lend more flexibility to high-rated countries to borrow more and follow expansionary policies. Second, based on the theory of PBC, we test how rating actions (upgrades or downgrades) alter fiscal discipline.

We estimate several empirical models of fiscal discipline based on rating levels and rating changes. We estimate the variants of the following two fixed effects models:

$$
\begin{aligned}
& \text { FISDISi, } \mathrm{t}=a+\beta_{\beta 1 R A T I N G \mathrm{i}, \mathrm{t}}+\beta_{\beta 2 C O N T R O L \mathrm{i}, \mathrm{t}}+\eta \mathrm{i}+v \mathrm{t}+\varepsilon \mathrm{it} \\
& \Delta F \text { ISDISi, } \mathrm{t}=a+\beta_{0}^{\circ} 1 \Delta R A T I N G \mathrm{i}, \mathrm{t}+\beta_{0} 2 \Delta \text { CONTROLi, } \mathrm{t}+\eta_{o} \mathrm{i}+v_{0} \mathrm{t}+\varepsilon_{0}
\end{aligned}
$$

where FISDIS is the term for fiscal discipline represented by FINBAL and DEBT, general government financial balance to GDP and general government debt to GDP respectively. RATING is the ordinal scale of 17 ratings given on long-term foreign currency denominated debt. $\Delta$ represents the level change of rating in a year. CONTROL is the set of control variables referring to governments' economic, financial and governance prospects. These variables include GDP percentage change (GDPPC), inflation (INF), ratio of domestic saving to GDP (SAVING), an openness indicator (OPENNESS), and the World Bank's worldwide governance indicators. These indicators measure institutional quality of countries from six different perspectives: government effectiveness, control of corruption, voice and accountability, political stability and absence of violence, regulatory quality and rule of law (GOV EFF, CORRUPTION, ACCOUNTABLE, POLSTA, REGQUA and $L A W$ ). $\eta$ i is used for heterogeneous country fixed effects, $v$ is to control for time fixed effects and finally it is the error term.

Model 1 is estimated to test for the impact of pro-cyclicality and path-dependence of ratings. We employ $D E B T$ as the dependent variable. The other fiscal discipline variable FINBAL is by definition the difference between the revenues and expenditures in general government budgets. Hence a government's expenditure performance may not necessarily create a surplus for that year, 
since governments may not be fully capable of controlling revenues ${ }^{2}$. The empirical problem in estimating Model 1 is that fiscal performance indicators may not always represent the performance of a given year. Governments' high performance in reducing debt levels may not lead to a sharp correction in debt stock level. High persistence in fiscal discipline indicators introduces a serial correlation problem in error terms. We estimate the models using an AR(1) disturbance term to overcome the serial correlation problem. To allow for the continued effect of ratings, we incorporate two lags of the level of ratings. This process also enhances the model by absorbing the serial correlation in the residuals (Hardouvelis and Theodossiou, 2002).

Model 2 is estimated to test the validity of the theory of PBC in sovereign debt space. The occurrence of rating upgrades is expected to prompt governments to borrow (and spend) opportunistically to attract support for the next election. We augment the specification in Model 2 by transforming level variables to annual changes similarly to Aizenman et al. (2013). In doing so, we estimate how changes in ratings and other control variables affect the changes in sovereign debt levels.

Since fiscal discipline figures are likely to be affected by their prior status, the formulation in Model 1 and 2 needs to be dynamic in nature. The dynamic panel formulation in Models 1 and 2 is a potential cause of dynamic panel bias that a fixed effect estimator can not eliminate especially when the panel's time dimension is not large enough (Nickell, 1981). Since the time dimension of the panel data used in this study is short, in order to suppress this bias, we need to apply dynamic panel linear techniques to check the validity of the chosen specifications in Models 1 and 2 . We also estimate Models 1 and 2 with system generalized method of moments (system-GMM) (Arellano and Bover, 1995; Blundell and Bond, 1998) using lagged first differences as instruments. We take the variables of the fiscal discipline indicators (DEBT and FINBAL) and ratings (RATING) as predetermined, meaning that current values of these variables can be correlated with past and current error terms but not with future error terms. The control variables are taken to be exogenous to limit the number of instruments due to over-identifying restrictions (OIR). Furthermore, we use two-step GMM estimation and the Windmeijer (2005) correction that minimizes the downward bias in standard errors. We test the system-GMM models for second order serial correlation and

${ }^{2}$ For instance, in crisis years the fiscal balance figures generally deteriorate not necessarily due to expansionary policies but to reduced revenues. 
OIR.

We present the expected signs of each variable in Table 1 . RATING term in Model 1 should be positively related to FISDIS $(\beta>0)$ if higher ratings lead to more borrowing incentives (procyclicality and path-dependence of ratings). Likewise, $\triangle R A T I N G\left(\beta^{0}>0\right)$ is expected to enter Model 2 with a positive sign indicating opportunistic political behaviour (the theory of PBC). We expect that control variables GDPPC, SAVING and OPENNESS will enter the equations with a negative sign. Higher GDP growth and savings rates along with better foreign trade performance plausibly impede governments' borrowing needs. Following a similar reasoning, the rise in INF is probably associated with higher borrowing needs. The stylized facts suggest that governments may opt to accelerate borrowing to absorb excess liquidity in the markets in high inflation episodes. In addition, governments can have fiscal expansionary policies that have inflationary effects. In both scenarios, high inflation is expected to have distortionary effects on fiscal discipline.

\section{Results}

In this section, we first present the descriptive statistics and then discuss the main findings.

\subsection{Descriptive Statistics}

We provide descriptive statistics and mean comparison tests for a sample of 1022 country-year observations in Table 3. The statistics follow a clear pattern showing that, on average, developing countries are assigned lower ratings than developed countries. This is expected since the country fundamentals of developed countries are more promising and institutional quality in these countries is more established. Conversely, the fiscal discipline figures present a mixed picture for developed and developing countries. Developed countries have 3.78\% significantly higher debt to GDP ratio than developing countries, on average. However, financial balance produces surplus in developed countries but deficit in developing countries. The difference between developed and developing countries (-3.2\%) is statistically significant. Other control variables and governance indicators suggest that developed countries have better institutional quality, low inflation, high saving rates and more openness in foreign trade. Percentage change in GDP is significantly higher in developing countries, showing remarkably high growth rates in these countries during the last decade. 
-INSERT TABLE 3 AROUND HERE-

Table 3 presents mean comparison tests for the pre-crisis (before 2008) and post-crisis (after 2008) periods. On average, there is no significant difference between pre- and post-crisis periods for most of the variables. As for the dependent variables used in the regressions, the average $D E B T$ figures do not show a significant difference between pre- and post-crisis periods, whereas FINBAL worsened significantly during the post-crisis period. This is probably due to expansionary policies and decelerated revenues regardless of country-specific circumstances. Variables that show significant differences between pre- and post-crisis periods are saving ratios, which show a considerable deceleration, probably due to income shocks that reduced households' saving propensities in the post-crisis period. Likewise, openness figures fell remarkably, which can be explained by the widespread protectionist policies implemented just after the 2008 crisis.

\subsection{Main Findings}

Before running the analyses proposed by Models 1 and 2 we checked for multicollinearity of the data. Table 4 shows that the correlation among the data is low, suggesting that multicollinearity is not a concern.

\section{-INSERT TABLE 4 AROUND HERE-}

We present our estimation results in the following sequence. Our main fiscal discipline measure in Models 1 and 2 is a sovereign debt ratio, measured by general government debt as a percentage of GDP (DEBT). We first estimate a simple specification in Table 5 to test whether high ratings are conducive to high debt levels (Model 1). In Table 6, we estimate the main specification in Model 2 to test how governments respond to rating changes. We estimate the extent to which institutional quality is effective in governments' responses to rating changes in Table 7. In a similar specification, we explore the effect of country classification as developed and developing in Table 8.

\section{-INSERT TABLE 5 AROUND HERE-}

Table 5 presents the estimation results for the relationship between debt to GDP ratios and ratings. We include one and two year lagged values of RATING in the specifications to contain continued effects of past level of ratings. The first column presents the model without any control variables. In the remaining columns, the control variables enter into the specifications interchangeably. We use the six World Bank governance indicators in the regressions. Identifying the most 
appropriate governance indicator is a complicated task in empirical studies (Ozturk, 2015; Thomas, 2010). Among many other perspectives, government effectiveness is of vital importance for politicians to adopt credible fiscal policies. The indicator demonstrates the quality of public services, the degree of independence from political pressures and the credibility of a government's commitment to the formulation of policies. Marcel (2013) posits that fiscal discipline is a combination of fiscal policy and government effectiveness. In a stronger statement, Andrews (2010) argues that government effectiveness is "...the most prominent indicator" of the World Bank governance indicators. In public policy literature, government effectiveness is predominantly incorporated to the analysis (see e.g. Afonso et al., 2010; Butkiewicz and Yanikkaya, 2011; Ligthart and van Oudheusden, 2015). We employ government effectiveness to proxy institutional quality in our models, but in Table 5 we present several other results which incorporate the other World Bank governance indicators. This allows us to observe how sensitive the main results are to variable selection.

The results presented in Table 5 confirm our initial expectations. GDPPC, SAVING and OPENNESS enter the equations with a negative sign suggesting that growing economy, larger share of savings in GDP and high openness in foreign trade tends to reduce DEBT. INF is estimated with a positive sign as expected, indicating that governments tend to borrow more in increasing inflationary environments. Although the coefficient estimates of SAVING are insignificant, the other coefficient estimates are significant at different statistical degrees. We have mixed results for the different dimensions of institutional quality. The results suggest that government effectiveness is negatively associated with general government debt to GDP confirming the results of previous literature (Afonso et al., 2010; Butkiewicz and Yanikkaya, 2011; Ligthart and van Oud-heusden, 2015). The coefficient estimates of lagged ratings (RATINGt_1 and RATINGt_2) have significant results. The joint effect of lagged rating variables (RATINGt_1 + RATINGt_2) and (RATING2 $\left.\iota_{1}+\mathrm{RATING}_{2} \_2\right)$ is significantly positive at different levels ${ }^{3}$. Taken together, the results show that higher ratings allow a favourable environment for borrowing. The model estimated in Table 5 incorporates varying degrees of ratings effects on debt to GDP ratio. While the positive relationship between ratings and debt to GDP ratios remains unchanged, the specifications of non-linear effects suggest that the degree of increase in debt levels with respect to ratings falls with higher ratings.

${ }^{3}$ We do not report F-test results here but they are available upon request. 
Table 5 presents the same specifications with the system-GMM estimator. We treated DEBT and RATING as predetermined, meaning that current values of these variables can be correlated with past and current error terms but not with future error terms. The control variables are taken to be exogenous to limit the number of instruments due to over-identifying restrictions (OIR). The regressions pass the $\mathrm{AR}(2)$ and Hansen OIR specification tests, indicating the validity of the instruments. The estimation results fully confirm the findings of the fixed effects results presented in the same table. The results of the system-GMM estimations suggest that high rated countries are more likely to borrow and accumulate debt. However, non-linear effects of ratings point to a negative incremental increase with increasing ratings.

We find supporting evidence for Hypothesis 1, which posited that high ratings create incentives for higher sovereign debt. The results suggest that when ratings increase, countries tend to borrow more. This finding is robust to different specifications and estimation approaches.

\section{-INSERT TABLE 6 AROUND HERE-}

We assess the presence of opportunistic politicians by estimating Model 2. Our main hypothesis is that opportunistic politicians borrow more in the presence of positive sentiment following a rating upgrade (Hypothesis 2). It may be a consistent motive for politicians to depart from fiscal discipline to guarantee their seat at the next elections. Table 6 reports the results for the relationship between rating changes and fiscal discipline. Interestingly, the estimation results show that countries make an effort to reduce debt levels following a rating upgrade; in other words, rating upgrades are generally accompanied by increased fiscal discipline in the following year. We present the systemGMM results in the same table. The results fully confirm the findings in fixed effects estimations. These results do not support the arguments of Hypothesis 2. Politicians find further support for fiscal discipline after a rating upgrade.

The finding of a significant relationship between rating changes and fiscal discipline might be dependent on a country's level of development and degree of institutional quality. Although we estimate the models by controlling for cross-country heterogeneity, the fiscal discipline-rating nexus may take different forms depending on a country's level of development and highly heterogeneous institutional quality, institutional enforcements etc.

\section{-INSERT TABLE 7 AROUND HERE-}

We initially estimate how the rating upgrades and fiscal behaviour relationship varies with the 
degree of institutional quality. We introduce an interaction term ( $\triangle$ RATINGt-1*GOV EFF) in the specification presented in Model 2 to capture the impact of institutional quality. Table 7 presents the results from the specifications containing the interaction term. The coefficient estimate of $\triangle R A T I N G t-1 * G O V E F F$ is negative in fixed effects and system-GMM results. The results suggest that rating upgrades in countries with higher levels of institutional quality lead to stronger fiscal discipline.

\section{-INSERT TABLE 8 AROUND HERE-}

Finally, we distinguish between developed and developing countries to detect possible differences in the relationship between rating changes and fiscal behaviour. Table 8 presents the results when the interaction term $\triangle$ RATINGt-1*DEV is incorporated into the Model 2. The variable $D E V$ is a dummy to capture the level of development that is defined according to the classification of the World Bank (see Table 2). We define developed country if a country is classified either in high income: $O E C D$ or high income: non-OECD. The countries of low income, lower middle income, and upper middle income are grouped as developing countries. The results suggest a significant and higher fiscal discipline in developed countries. We however note that the impact of being a developed country is weaker than the impact of institutional quality. From this we infer that the significant relationship between rating changes and fiscal behaviour for the whole sample is associated mainly with the institutional quality rather than the level of development.

The results based on institutional quality and country segregation provide valuable insights into the role of ratings in fiscal discipline. They suggest that in developing countries ratings only play a significant role in the way they influence borrowing behaviour. Moreover, the role of ratings in fiscal discipline is strengthened by the degree of institutional quality in developing countries. Developing countries with higher levels of institutional quality have more incentive to discipline government indebtedness. Developing countries that have weaker institutions, however, have only a weak incentive for fiscal discipline. All our results support the previous finding in the literature that institutional quality plays a significant role in fiscal discipline and borrowing behaviour.

\subsection{Robustness Checks}

In this section, we present several robustness checks. We firstly study an alternative measure of fiscal discipline, namely general government budget balance (FINBAL) to examine fiscal behaviour 
responses to rating changes (Vlaicu et al., 2014). We consider that budget balance figures tend to worsen following a rating upgrade. We present both fixed effect and system-GMM results together to observe whether endogeneity issues alter the main findings. We should add a cautionary note here since financial balance is the difference between general government revenues and expenditures. The volatility in general government revenues may cause unexpected shocks to the balance. This is especially true during the episodes of crisis. However, since our sample does not contain periods when government revenues were severely hit by the crisis, we can safely employ FINBAL as an alternative fiscal discipline measure. The results show that when the dependent variable is general government fiscal balance to GDP, FINBAL, rating changes hinder politicians from increasing public spending. We then arrive at a more conclusive result that governments tend to reduce borrowing and cut expenditure which taken together results in a better fiscal discipline.

-INSERT TABLE 9 AROUND HERE-

We check the robustness of our results with additional tests. For reasons of space we do not present the results in the paper but they are available upon request. In the second robustness check, we restrict our sample by removing years 2009 and 2010 to exclude any potential crisis effect. We know that after the crisis several countries faced downgrades and severe worsening of fiscal stance. Downgrades with worsening fiscal discipline might have created a spurious relationship between downgrades and worsening fiscal discipline in earlier estimations. When we exclude those years, the regression outputs clearly confirm our fundamental findings.

Finally, we estimate an ordered probit model to explore whether or not rating changes trigger improvement/deterioration in fiscal discipline. The fiscal discipline variables take three categories as improvement:3, no change: 2 and deterioration: $1^{4}$. Because of the natural ordering of fiscal discipline, ordered probit modelling is applied to estimate the models in this study.

Let $y_{i t}$ be the propensity for the changes in fiscal discipline of country $i$ at time $t$.

$$
y i t=\beta^{\prime} x i t+\text { uit }
$$

\footnotetext{
${ }^{4}$ Since no change in a continuous time series is highly unlikely, we accept changes within $2 \%$ as no change. We tried several other intervals upto $2 \%$ as no change, the results are unchanged.
} 
where $\beta$ is a $k x 1$ parameter vector, xit is a $k x 1$ vector for the individual characteristics measured at time $t$ and uit is the stochastic disturbance term. The observability criterion for the three possible outcomes in the model is given by:

$$
\text { Sit }=\mathrm{s} \text { if } \mu \mathrm{s}_{-} 1 \delta \text { yit } \delta \mu_{\mathrm{s}} \text { for } \mathrm{s}=1,2,3
$$

where $\mathbf{S}=\left\{\begin{array}{r}3 \text { if the country shows improvement in fiscal discipline } 2 \\ \text { if the country shows no change in fiscal discipline } \\ 1 \text { if the country shows deterioration in fiscal discipline }\end{array}\right.$

Note that $\mu$ 's are the threshold values where $\mu 0<\mu 1<\mu 2<\mu 3, \mu 0=$ and $\mu 3=+$. The conditional probability of observing the $s^{\text {th }}$ category for country $\mathbf{i}$ is then:

$$
\operatorname{Pr}(\text { Sit }=s \mid \text { xit })=\operatorname{Pr}\left(\mu s_{-} 1 \delta \beta^{\prime} \text { xit }+ \text { uit } \delta \mu_{s}\right)
$$

Assuming a standard normal distribution for the stochastic disturbance term (uit $<\mathbf{N}(0,1)$ ), and arranging the terms above, the conditional probabilities could be written as 5 :

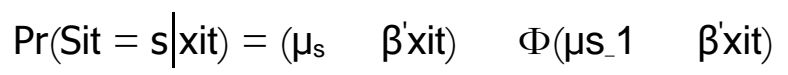

where is the normal probability density function with $(\quad)=0$ and $(+\quad)=1$.

$$
\text { -INSERT TABLE } 10 \text { AROUND HERE- }
$$

By estimating the probit model, we obtain similar results on the rating changes and fiscal discipline suggesting that rating upgrades further lead to fiscal discipline (see Table 10).

\section{Conclusion}

The role of ratings in fiscal discipline has been frequently visited, but the empirical evidence on the subject is somewhat scarce. The issue of fiscal discipline has proved to be pervasive since

${ }^{5}$ We also estimate the whole model by ordered logit model. The model takes the form of ordered logit if we assume a logistic distribution for the disturbance term. 
several EU countries were downgraded as a result of their huge fiscal deficits. This paper discusses various aspects of the ratings-fiscal discipline nexus.

The study provides rich insights into the impact of ratings and rating changes on fiscal discipline. Firstly, we find evidence that higher ratings are associated with looser fiscal discipline (Hypothesis 1). We argue that this is the direct result of pro-cyclicality and path dependence of ratings. Secondly, the behaviour of governments towards rating changes does not support the theory of PBC. The results conflict with the theory, suggesting that rating upgrades motivate governments to further discipline their fiscal figures (Hypothesis 2). Finally, we find that the ratings-fiscal discipline nexus is dependent on countries' institutional quality and level of development (Hypothesis 3). The significant relationship between rating changes and fiscal discipline is found to be stronger in those countries of better institutional quality which may not be necessarily associated with the level of development.

The findings in this paper clearly indicate that the implications of the pro-cyclicality and the path dependence of ratings work to tighten up looser fiscal discipline. The belief that ratings do not change so much is an impediment for fiscal discipline among high-rated countries. This belief is partly nurtured by the asymmetric impact of ratings for high and low-rated countries. The Basel regulations impose harsher punishments for low ratings, but greatly favour high ratings. Therefore, low-rated countries can only borrow from a limited number of creditors, but high-rated countries can take advantage of a large pool of funding available to them at lower costs. This paper also shows that governments do not opt to exploit the favourable environment that a rating upgrade creates. The relaxation of credit constraints does not lead to reckless borrowing and consequent further debt burden.

The paper provides evidence that institutional quality plays a significant role in fiscal discipline. The countries that manage to separate politics from public services are more successful in terms of fiscal discipline when ratings are upgraded. We interpret this result as a reflection of governments' commitment to formulating and implementing policies that cannot be distorted by short-term political ambitions. These findings lend support to the conclusion in the existing literature that institutional quality plays a significant role in fiscal discipline and borrowing behaviour. Endeavours to improve the quality of institutions will be influential in maintaining fiscal discipline and lead to subsequent higher ratings. 
Our findings have implications for the highly debated issues of ratings and CRAs after the 2008 crisis. The EU fiscal crisis that originated in highly indebted EU countries is at least amplified by the pro-cyclicality and path dependence of ratings. The belief that high government debt would not be punished by the CRAs led to a considerable amount of debt accumulation in many EU countries. The generous ratings in the boom phase of global economy and incremental downgrades even after 2008 instigated harsh debates about the pro-cyclicality and path dependence of ratings. The candid intentions to find solutions not only to the issues of procyclicality and path dependence but many other concerns in credit risk assessments should be regarded as a welcome sign of better regulation. 


\section{References}

Afonso, A., Agnello, L., and Furceri, D. (2010). Fiscal Policy Responsiveness, Persistence, and Discretion. Public Choice, 145(3):503-530.

Afonso, A. and Gomes, P. (2011). Do Fiscal Imbalances Deteriorate Sovereign Debt Ratings? Revue 'Economique, 62(6):1123-1134.

Aizenman, J., Binici, M., and Hutchison, M. (2013). Credit Ratings and the Pricing of Sovereign Debt During the Euro Crisis. Oxford Review of Economic Policy, 29(3):582-609.

Akhmedov, A. and Zhuravskaya, E. (2004). Opportunistic Political Cycles: Test in A Young Democracy Setting. The Quarterly Journal of Economics, 119(4):1301-1338.

Andrews, M. (2010). Good Government Means Different Things in Different Countries. Governance, 23(1):7-35.

Arellano, M. and Bover, O. (1995). Another Look at the Instrumental Variable Estimation of ErrorComponents Models. Journal of Econometrics, 68(1):29-51.

Balassone, F., Franco, D., and Zotteri, S. (2006). EMU Fiscal Indicators: A Misleading Compass? Empirica, 33(2-3):63-87.

Bangia, A., Diebold, F. X., Kronimus, A., Schagen, C., and Schuermann, T. (2002). Ratings Migration and the Business Cycle, with Application to Credit Portfolio Stress Testing. Journal of Banking \& Finance, 26(2-3):445-474.

Berger, H. and Woitek, U. (1997). How Opportunistic are Partisan German Central Bankers: Evidence on the Vaubel Hypothesis. European Journal of Political Economy, 13(4):807-821.

Block, S. A. (2002). Political Business Cycles, Democratization, and Economic Reform: the Case of Africa. Journal of Development Economics, 67(1):205-228.

Block, S. A. and Vaaler, P. M. (2004). The Price of Democracy: Sovereign Risk Ratings, Bond Spreads and Political Business Cycles in Developing Countries. Journal of International Money and Finance, 23(6):917-946. 
Blundell, R. and Bond, S. (1998). Initial Conditions and Moment Restrictions in Dynamic Panel Data Models. Journal of Econometrics, 87(1):115-143.

Butkiewicz, J. L. and Yanikkaya, H. (2011). Institutions and the Impact of Government Spending on Growth. Journal of Applied Economics, 0:319-341.

Cantor, R. and Packer, F. (1995). Sovereign Credit Ratings. Current Issues in Economics and Finance, 1(Jun).

Cantor, R. and Packer, F. (1996). Determinants and Impact of Sovereign Credit Ratings. Economic Policy Review, (Oct):37-53.

Celasun, O. and Harms, P. (2011). Boon Or Burden? The Effect Of Private Sector Debt On The Risk Of Sovereign Default In Developing Countries. Economic Inquiry, 49(1):70-88.

Dimitrakopoulos, S. and Kolossiatis, M. (2015). State Dependence and Stickiness of Sovereign Credit Ratings: Evidence from a Panel of Countries. Journal of Applied Econometrics, page forthcoming.

Eijffinger, S. (2012). Rating Agencies: Role and Influence of Their Sovereign Credit Risk Assessment in the Eurozone. Journal of Common Market Studies, 50(6):912-921.

Erdem, O. and Varli, Y. (2014). Understanding the Sovereign Credit Ratings of Emerging Markets. Emerging Markets Review, 20(C):42-57.

Ferri, G., Liu, L.-G., and Stiglitz, J. E. (1999). The Procyclical Role of Rating Agencies: Evidence from the East Asian Crisis. Economic Notes, 28(3):335-355.

Fitch Ratings (2012). Sovereign Rating Criteria. Technical report.

G*artner, M., Griesbach, B., and Jung, F. (2011). PIGS or Lambs? The European Sovereign Debt Crisis and the Role of Rating Agencies. International Advances in Economic Research, 17(3):288-299.

Gavin, M. and Perotti, R. (1997). Fiscal Policy in Latin America. In NBER Macroeconomics Annual 1997, Volume 12, NBER Chapters, pages 11-72. National Bureau of Economic Research, Inc. 
Gültekin-Karakass, D., Hisarciklilar, M., and "Oztürk, H. (2011). Sovereign Risk Ratings: Biased Toward Developed Countries? Emerging Markets Finance and Trade, 47(0):69-87.

Hanusch, M. and Vaaler, P. M. (2013). Credit Rating Agencies and Elections in Emerging Democracies: Guardians of Fiscal Discipline? Economics Letters, 119(3):251-254.

Hardouvelis, G. A. and Theodossiou, P. (2002). The Asymmetric Relation Between Initial Margin Requirements and Stock Market Volatility Across Bull and Bear Markets. Review of Financial Studies, 15(5):1525-1560.

Hibbs, Douglas A, J. (1986). Political Parties and Macroeconomic Policies and Outcomes in the United States. American Economic Review, 76(2):66-70.

Kaufmann, D., Kraay, A., and Zoido, P. (1999). Governance Matters. World Bank Policy Research Working Paper 2196, World Bank.

Klein, F. A. and Sakurai, S. N. (2015). Term Limits and Political Budget Cycles at the Local Level: Evidence from a Young Democracy. European Journal of Political Economy, 37(C):21-36.

Kumar, M. and Ter-Minassian, T. (2007). Promoting Fiscal Discipline. International Monetary Fund.

Ligthart, J. E. and van Oudheusden, P. (2015). In Government We Trust: The Role of Fiscal Decentralization. European Journal of Political Economy, 37(C):116-128.

Marcel, M. (2013). Budgeting for Fiscal Space and Government Performance Beyond the Great Recession. OECD Journal on Budgeting, 13(2):9-47.

Mulder, C. B. and Monfort, B. (2000). Using Credit Ratings for Capital Requirements on Lending to Emerging Market Economies: Possible Impact of a New Basel Accord. IMF Working Papers 00/69, International Monetary Fund.

Nickell, S. J. (1981). Biases in Dynamic Models with Fixed Effects. Econometrica, 49(6):1417-26.

Nordhaus, W. D. (1975). The Political Business Cycle. Review of Economic Studies, 42(2):169-90.

Ozturk, H. (2015). Reliance of Sovereign Credit Ratings on Governance Indicators. European Journal of Development Research, page forthcoming. 
Pagano, M. and Volpin, P. (2010). Credit Ratings Failures and Policy Options. Economic Policy, 25:401-431.

Panizza, U., Sturzenegger, F., and Zettelmeyer, J. (2009). The Economics and Law of Sovereign Debt and Default. Journal of Economic Literature, 47(3):651-98.

Paudyn, B. (2013). Credit Rating Agencies and the Sovereign Debt Crisis: Performing the Politics of Creditworthiness Through Risk and Uncertainty. Review of International Political Economy, 20(4):788818.

Peters, A. C. (2010). Election Induced Fiscal and Monetary Cycles:Evidence from the Caribbean. Journal of Developing Areas, 44(1):287-303.

Sakurai, S. and Menezes-Filho, N. (2008). Fiscal Policy and Reelection in Brazilian Municipalities. Public Choice, 137(1):301-314.

Schuknecht, L. (1996). Political Business Cycles and Fiscal Policies in Developing Countries. Kyklos, 49(2):155-70.

Thomas, M. A. (2010). What Do the Worldwide Governance Indicators Measure? The European Journal of Development Research, 22(1):31-54.

Vaaler, P. M., Schrage, B. N., and Block, S. A. (2006). Elections, Opportunism, Partisanship and Sovereign Ratings in Developing Countries. Review of Development Economics, 10(1):154-170.

Vlaicu, R., Verhoeven, M., Grigoli, F., and Mills, Z. (2014). Multiyear Budgets and Fiscal Performance: Panel Data Evidence. Journal of Public Economics, 111(C):79-95.

White, L. J. (2010). Markets: The Credit Rating Agencies. Journal of Economic Perspectives, 24(2):21126.

Windmeijer, F. (2005). A Finite Sample Correction for the Variance of Linear Efficient Two-step GMM Estimators. Journal of Econometrics, 126(1):25-51.

Yeyati, E. L. (2009). Optimal Debt? On the Insurance Value of International Debt Flows to Developing Countries. Open Economies Review, 20(4):489-507. 


\section{Tables}

Table 1: Variable Definitions and Sources

\begin{tabular}{|c|c|c|c|}
\hline Variable & Descrintion & Source & Exnected Signs \\
\hline$D E B T$ & General government debt/GDP & Moody's & \\
\hline FINBAL & General government budget balance & Moody's & \\
\hline RATING & Moody’s ratings (Caa1:1,Aaa:16) & Moody's & + \\
\hline GOV EFF & Government effectiveness & The World Bank & $+/-$ \\
\hline CORRUPTION & Control of corruption & The World Bank & $+/-$ \\
\hline ACCOUNTABLE & Voice and accountability & The World Bank & $+/-$ \\
\hline POLSTA & Political stability and absence of violence and terrorism & The World Bank & $+/-$ \\
\hline$R E G Q U A$ & Regulatory quality & The World Bank & $+/-$ \\
\hline$L A W$ & Rule of law & The World Bank & $+/-$ \\
\hline$G D P P C$ & GDP percentage change in US dollars (nominal) & Moody’s & - \\
\hline SAVING & Domestic savings/GDP & Moody's & - \\
\hline OPENNESS & Sum of exports and imports of goods and services/GDP & Moody's & - \\
\hline INF & Annual change in consumer prices & Moody’s & + \\
\hline
\end{tabular}

Notes: The table demonstrates the variables, their descriptions and sources. The table shows expected signs of parameter estimates in regression analysis.

Table 2: Distribution of countries by income group

\begin{tabular}{lcc}
\hline \hline Incomegroup & Frequency & Percentage \\
Low income & 3 & 3.23 \\
Lower middle income & 21 & 22.58 \\
Upper middle income & 25 & 26.88 \\
High income: OECD & 27 & 29.03 \\
High income: non-OECD & 17 & 18.28 \\
Total & 93 & 100.00
\end{tabular}

Notes: The classification is based on the World Bank definition. 


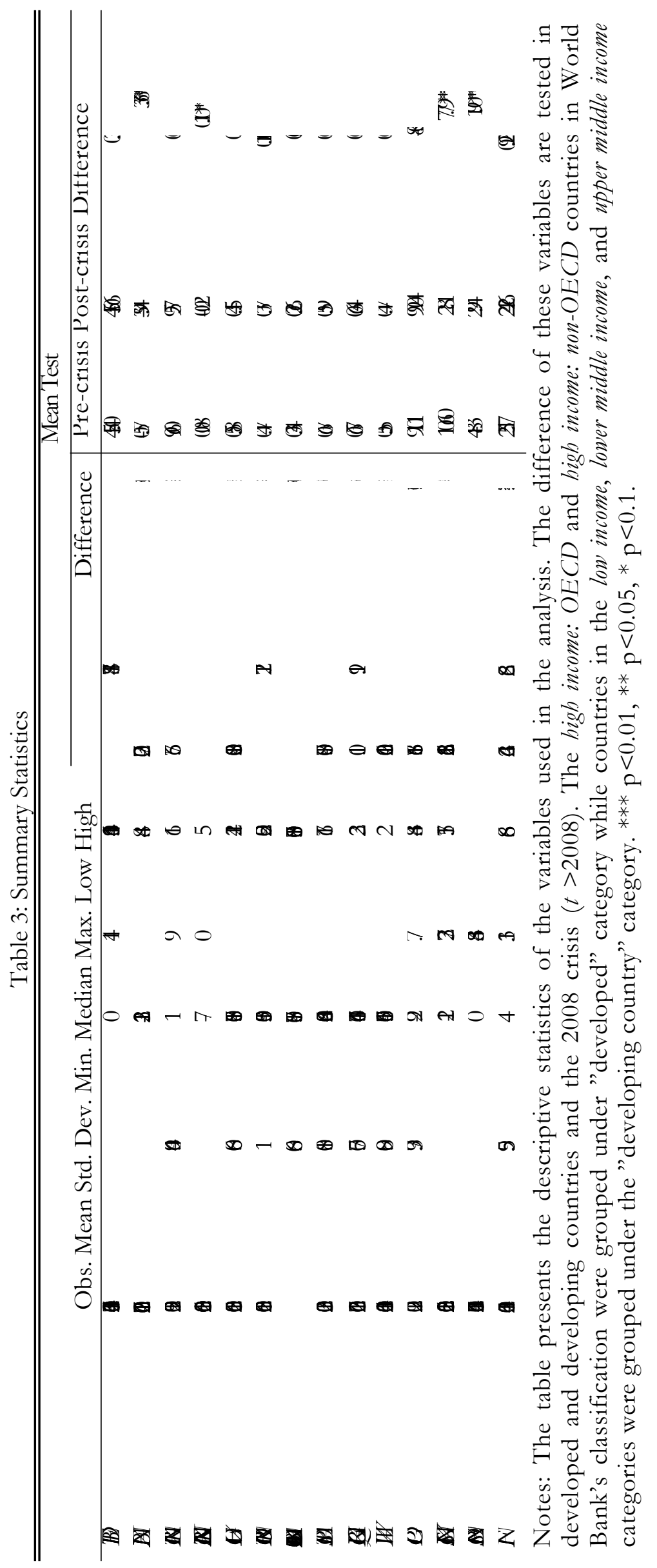




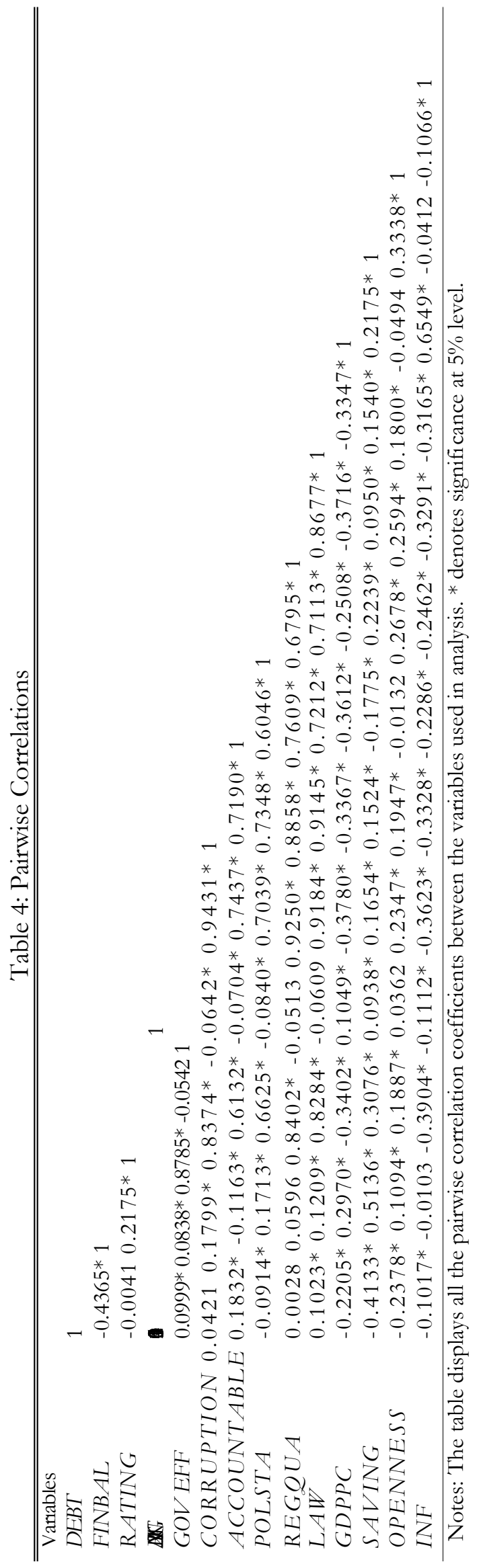


Table 5: Level of Sovereign Debt and Ratings

\begin{tabular}{|c|c|c|c|c|c|c|c|c|}
\hline & \multicolumn{7}{|c|}{ Fixed Effects } & \multirow{2}{*}{$\frac{\text { System GMM }}{(8)}$} \\
\hline & (1) & (2) & (3) & (4) & (5) & (6) & (7) & \\
\hline$D E B T_{t}+1$ & $\begin{array}{c}0.910 * * * \\
(0.0305)\end{array}$ & $\begin{array}{c}0.911 * * * \\
(0.0302)\end{array}$ & $\begin{array}{c}0.902 * * * \\
(0.0304)\end{array}$ & $\begin{array}{c}0.905 * * * \\
(0.0300)\end{array}$ & $\begin{array}{c}0.907 * * * \\
(0.0299)\end{array}$ & $\begin{array}{c}0.903 * * * \\
(0.0282)\end{array}$ & $\begin{array}{c}0.897 * * * \\
(0.0285)\end{array}$ & $\begin{array}{c}0.855 * * * \\
(0.0657)\end{array}$ \\
\hline$\underset{j=1}{\mathrm{P}} \mathrm{RATING} \_j$ & $2.092 * * *$ & $2.093 * * *$ & $1.991 * * *$ & $1.960 * * *$ & $1.923 * * *$ & $1.675 * * *$ & $1.781 * * *$ & $4.559 * * *$ \\
\hline 更 & $(0.638)$ & $(0.0276)$ & $(0.626)$ & $(0.662)$ & $(0.660)$ & $(0.0263)$ & $(0.0262)$ & $(-0.196)$ \\
\hline P $R A T I N G^{2}$ & $-0.0851 * * *$ & $-0.0736 * * *$ & $-0.0779 * * *$ & $-0.0796 * * *$ & $-0.0767 * * *$ & $-0.0916 * * *$ & $-0.094 * * *$ & -0.298 \\
\hline GOVEFF & $(0.0269)$ & $\begin{array}{c}(0.645) \\
-3.859 * * \\
(1.744)\end{array}$ & $(0.0274)$ & $(0.0282)$ & $(0.0281)$ & $(0.503)$ & $(0.529)$ & $\begin{array}{c}(2.693) \\
12.83 \\
(8.497)\end{array}$ \\
\hline CORRUPTION & & & $\begin{array}{l}-2.408 \\
(2.225)\end{array}$ & & & & & \\
\hline ACCOUNTABLE & & & & $\begin{array}{l}-0.508 \\
(1.863)\end{array}$ & & & & \\
\hline POLSTA & & & & & $\begin{array}{c}0.154 \\
(1.105)\end{array}$ & & & \\
\hline$R E G Q U A$ & & & & & & $\begin{array}{c}3.465 * * \\
(1.631)\end{array}$ & & \\
\hline$L A W$ & & & & & & & $\begin{array}{c}4.057 * * \\
(1.554)\end{array}$ & \\
\hline$G D P P C$ & & $\begin{array}{l}-0.107^{*} \\
(0.0566)\end{array}$ & $\begin{array}{l}-0.107^{*} \\
(0.0559)\end{array}$ & $\begin{array}{l}-0.107^{*} \\
(0.0557)\end{array}$ & $\begin{array}{l}-0.104^{*} \\
(0.0558)\end{array}$ & $\begin{array}{c}-0.267 * * * \\
(0.0485)\end{array}$ & $\begin{array}{c}-0.258 * * * \\
(0.0490)\end{array}$ & $\begin{array}{l}-0.545 \\
(0.475)\end{array}$ \\
\hline SAVING & & & & $\begin{array}{l}0.00643 \\
(0.0744)\end{array}$ & $\begin{array}{l}0.00623 \\
(0.0735)\end{array}$ & $\begin{array}{c}0.000384 \\
(0.0682)\end{array}$ & $\begin{array}{c}-0.000508 \\
(0.0674)\end{array}$ & $\begin{array}{l}-0.719 \\
(0.555)\end{array}$ \\
\hline OPENNESS & & & & & $\begin{array}{l}-0.0108 \\
(0.0148)\end{array}$ & $\begin{array}{l}-0.0196 \\
(0.0172)\end{array}$ & $\begin{array}{l}-0.0295^{*} \\
(0.0150)\end{array}$ & $\begin{array}{l}-0.0501 \\
(0.0990)\end{array}$ \\
\hline$I N F$ & & & & & & $\begin{array}{c}0.539 * * * \\
(0.149)\end{array}$ & $\begin{array}{c}0.545 * * * \\
(0.153)\end{array}$ & $\begin{array}{c}0.963 * * * \\
(0.369)\end{array}$ \\
\hline CONSTANT & $\begin{array}{l}-4.033 \\
(4.349)\end{array}$ & $\begin{array}{l}-1.971 \\
(4.008)\end{array}$ & $\begin{array}{l}-1.342 \\
(3.870)\end{array}$ & $\begin{array}{l}-2.342 \\
(4.031)\end{array}$ & $\begin{array}{l}-2.759 \\
(3.911)\end{array}$ & $\begin{array}{l}-1.024 \\
(3.735)\end{array}$ & $\begin{array}{l}-0.392 \\
(3.552)\end{array}$ & $\begin{array}{c}12.43 \\
(11.84)\end{array}$ \\
\hline Observations & 836 & 836 & 836 & 836 & 836 & 836 & 836 & 836 \\
\hline Number of countries & 93 & 93 & 93 & 93 & 93 & 93 & 93 & 93 \\
\hline$R$-squared & 0.779 & 0.785 & 0.784 & 0.783 & 0.783 & 0.810 & 0.810 & \\
\hline $\begin{array}{l}\text { Number of instruments } \\
\text { ARI }\end{array}$ & & & & & & & & $\begin{array}{c}30 \\
0.017\end{array}$ \\
\hline$A R 2$ & & & & & & & & 0.145 \\
\hline Hansen OIR test p-value & & & & & & & & 0.619 \\
\hline
\end{tabular}

Notes: The table displays both the fixed effects and the system GMM regression results. The dependent variable is DEBT. The definition of dependent variable and regressors are defined in Table 1. Regarding the system GMM regressions, we estimate two-step system GMM estimation with Windmeijer (2005) correction. Robust standard errors are in parenthesis. The figures in parentheses

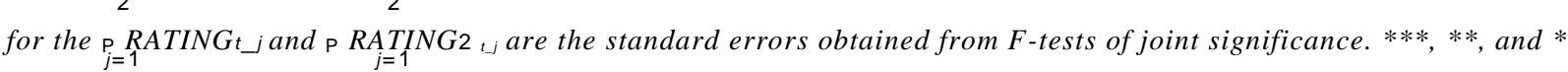
indicate statistical significance at $1 \%, 5 \%$, and $10 \%$. 
Table 6: Sovereign Debt Responses to Rating Changes

\begin{tabular}{|c|c|c|c|c|c|c|c|}
\hline & \multirow[b]{2}{*}{ (1) } & \multirow[b]{2}{*}{ (2) } & \multicolumn{2}{|c|}{ Fixed Effects } & \multirow[b]{2}{*}{ (5) } & \multirow[b]{2}{*}{ (6) } & \multirow{2}{*}{$\begin{array}{c}\text { System GMM } \\
(7)\end{array}$} \\
\hline & & & (3) & (4) & & & \\
\hline$\triangle D E B T \mathrm{t}-1$ & & & & & & & $\begin{array}{c}0.251 * * * \\
(0.001)\end{array}$ \\
\hline$\triangle R A T I N G \mathrm{t}-1$ & $\begin{array}{r}-1.914 * * \\
(0.961)\end{array}$ & $\begin{array}{c}-1.995 * * \\
(0.949)\end{array}$ & $\begin{array}{c}-1.993 * * \\
(0.950)\end{array}$ & $\begin{array}{c}-2.419 * * \\
(1.028)\end{array}$ & $\begin{array}{c}-2.386 * * \\
(1.019)\end{array}$ & $\begin{array}{c}-2.377 * * \\
(1.019)\end{array}$ & $\begin{array}{c}-3.732 * * \\
(0.019)\end{array}$ \\
\hline$G D P P C$ & & $\begin{array}{c}-0.147 * * * \\
(0.0557)\end{array}$ & $\begin{array}{c}-0.147 * * * \\
(0.0557)\end{array}$ & $\begin{array}{l}-0.157 * * \\
(0.0631)\end{array}$ & $\begin{array}{l}-0.172 * * \\
(0.0724)\end{array}$ & $\begin{array}{l}-0.170 * * \\
(0.0731)\end{array}$ & $\begin{array}{c}-0.202 * * * \\
(0.000)\end{array}$ \\
\hline$\triangle G O V E F F$ & & & $\begin{array}{l}-0.173 \\
(1.197)\end{array}$ & $\begin{array}{c}-0.644 \\
(1.171)\end{array}$ & $\begin{array}{l}-0.595 \\
(1.156)\end{array}$ & $\begin{array}{l}-0.573 \\
(1.151)\end{array}$ & $\begin{array}{l}-0.157 \\
(0.904)\end{array}$ \\
\hline$\Delta I N F$ & & & & $\begin{array}{l}0.334 * * * \\
(0.0880)\end{array}$ & $\begin{array}{l}0.330 * * * \\
(0.0862)\end{array}$ & $\begin{array}{l}0.324 * * * \\
(0.0862)\end{array}$ & $\begin{array}{c}0.424 * * * \\
(0.000)\end{array}$ \\
\hline$\triangle S A V I N G$ & & & & & $\begin{array}{c}0.0797 \\
(0.0770)\end{array}$ & $\begin{array}{c}0.0806 \\
(0.0774)\end{array}$ & $\begin{array}{c}0.054 \\
(0.464)\end{array}$ \\
\hline$\triangle O P E N N E S S$ & & & & & & $\begin{array}{c}0.0154 \\
(0.0235)\end{array}$ & $\begin{array}{l}-0.082 \\
(0.333)\end{array}$ \\
\hline CONSTANT & $\begin{array}{c}1.848 * * \\
(0.770)\end{array}$ & $\begin{array}{c}5.503 * * * \\
(0.526)\end{array}$ & $\begin{array}{c}5.505 * * * \\
(0.527)\end{array}$ & $\begin{array}{c}6.894 * * * \\
(0.670)\end{array}$ & $\begin{array}{c}7.015 * * * \\
(0.711)\end{array}$ & $\begin{array}{c}7.192 * * * \\
(0.826)\end{array}$ & $\begin{array}{c}1.369 \\
(0.312)\end{array}$ \\
\hline Observations & 929 & 929 & 929 & 929 & 929 & 929 & 929 \\
\hline Number of countryid & 93 & 93 & 93 & 93 & 93 & 93 & 93 \\
\hline R-squared & 0.237 & 0.262 & 0.262 & 0.308 & 0.310 & 0.311 & \\
\hline Number of instruments & & & & & & & 34 \\
\hline AR1 & & & & & & & 0.001 \\
\hline AR2 & & & & & & & 0.226 \\
\hline Hansen OIR test p-value & & & & & & & 0.245 \\
\hline $\begin{array}{l}\text { Notes: The table display } \\
\text { annual change. The depe } \\
\text { are given in Table } 1 \text {. R } \\
\text { Windmeijer (2005) corr } \\
\text { statistical significance at }\end{array}$ & $\begin{array}{l}\text { both the fi } \\
\text { ent variabl } \\
\text { arding the } \\
\text { tion. Robu } \\
\%, 5 \% \text {, and }\end{array}$ & $\begin{array}{l}\text { xed effects } \\
\text { e is } \triangle D E B T \\
\text { system GN } \\
\text { st standard }\end{array}$ & $\begin{array}{l}\text { and the syst } \\
\text { The definit } \\
\text { AM regressi } \\
\text { errors are }\end{array}$ & $\begin{array}{l}\text { em GMM } \\
\text { ion of the d } \\
\text { ons, we est } \\
\text { given in pa }\end{array}$ & $\begin{array}{l}\text { egression } \\
\text { ependent } v \\
\text { imate two- } \\
\text { rentheses. }\end{array}$ & $\begin{array}{l}\text { esults. } \Delta \mathrm{d} \\
\text { rriable and } \\
\text { step syste } \\
* * *, * * \text {, a }\end{array}$ & $\begin{array}{l}\text { notes for the } \\
\text { he regressors } \\
\text { GMM with } \\
\text { d* indicate }\end{array}$ \\
\hline
\end{tabular}


Table 7: Sovereign Debt Responses to Rating Changes: The Impact of Institutional Quality

\begin{tabular}{|c|c|c|c|c|c|c|c|}
\hline & \multirow[b]{2}{*}{ (1) } & \multirow[b]{2}{*}{ (2) } & \multicolumn{2}{|c|}{ Fixed Effects } & \multirow[b]{2}{*}{ (5) } & \multirow[b]{2}{*}{ (6) } & \multirow{2}{*}{$\begin{array}{c}\text { System GMM } \\
\text { (7) }\end{array}$} \\
\hline & & & (3) & (4) & & & \\
\hline$\triangle D E B T \mathrm{t}-1$ & & & & & & & $\begin{array}{c}0.303 * * * \\
(0.007)\end{array}$ \\
\hline$\triangle R A T I N G \mathrm{t}-1$ & $\begin{array}{c}-0.557^{*} \\
(0.284)\end{array}$ & $\begin{array}{c}-0.702 * * \\
(0.319)\end{array}$ & $\begin{array}{c}-0.690 * * \\
(0.323)\end{array}$ & $\begin{array}{c}-1.177 * * \\
(0.495)\end{array}$ & $\begin{array}{c}-1.157 * * \\
(0.508)\end{array}$ & $\begin{array}{c}-1.134 * * \\
(0.501)\end{array}$ & $\begin{array}{l}-1.122 \\
(0.513)\end{array}$ \\
\hline$\triangle R A T I N G \mathrm{t}-1 *$ GOVEFF & $\begin{array}{c}-2.409 * * * \\
(0.616)\end{array}$ & $\begin{array}{c}-2.286 * * * \\
(0.670)\end{array}$ & $\begin{array}{c}-2.294 * * * \\
(0.677)\end{array}$ & $\begin{array}{c}-2.160 * * * \\
(0.707)\end{array}$ & $\begin{array}{c}-2.145^{* * * *} \\
(0.709)\end{array}$ & $\begin{array}{c}-2.163 * * * \\
(0.717)\end{array}$ & $\begin{array}{c}-1.825^{* *} \\
(0.045)\end{array}$ \\
\hline$G D P P C$ & & $\begin{array}{l}-0.138 * * \\
(0.0569)\end{array}$ & $\begin{array}{l}-0.137 * * \\
(0.0569)\end{array}$ & $\begin{array}{l}-0.148 * * \\
(0.0633)\end{array}$ & $\begin{array}{l}-0.161 * * \\
(0.0721)\end{array}$ & $\begin{array}{l}-0.158 * * \\
(0.0726)\end{array}$ & $\begin{array}{l}-0.189^{*} \\
(0.056)\end{array}$ \\
\hline$\triangle G O V E F F$ & & & $\begin{array}{l}-0.576 \\
(1.259)\end{array}$ & $\begin{array}{l}-1.008 \\
(1.256)\end{array}$ & $\begin{array}{l}-0.962 \\
(1.237)\end{array}$ & $\begin{array}{l}-0.933 \\
(1.229)\end{array}$ & $\begin{array}{l}-1.013 \\
(0.464)\end{array}$ \\
\hline$\Delta I N F$ & & & & $\begin{array}{l}0.323 * * * \\
(0.0851)\end{array}$ & $\begin{array}{l}0.319 * * * \\
(0.0836)\end{array}$ & $\begin{array}{l}0.310 * * * \\
(0.0827)\end{array}$ & $\begin{array}{c}0.652 * * * \\
(0.000)\end{array}$ \\
\hline$\triangle S A V I N G$ & & & & & $\begin{array}{c}0.0703 \\
(0.0755)\end{array}$ & $\begin{array}{c}0.0714 \\
(0.0761)\end{array}$ & $\begin{array}{c}0.01 \\
(0.976)\end{array}$ \\
\hline$\triangle O P E N N E S S$ & & & & & & $\begin{array}{c}0.0216 \\
(0.0252)\end{array}$ & $\begin{array}{l}-0.068 \\
(0.285)\end{array}$ \\
\hline CONSTANT & $\begin{array}{l}1.910 * * \\
(0.769)\end{array}$ & $\begin{array}{c}5.313 * * * \\
(0.462)\end{array}$ & $\begin{array}{c}5.318 * * * \\
(0.465)\end{array}$ & $\begin{array}{c}6.671 * * * \\
(0.542)\end{array}$ & $\begin{array}{c}6.779 * * * \\
(0.572)\end{array}$ & $\begin{array}{c}7.025^{* * * *} \\
(0.724)\end{array}$ & $\begin{array}{c}1.202 \\
(0.333)\end{array}$ \\
\hline Observations & 929 & 929 & 929 & 929 & 929 & 929 & 929 \\
\hline Number of countries & 93 & 93 & 93 & 93 & 93 & 93 & 93 \\
\hline R-squared & 0.268 & 0.289 & 0.289 & 0.333 & 0.334 & 0.335 & \\
\hline Number of instruments & & & & & & & 35 \\
\hline AR1 & & & & & & & 0.000 \\
\hline AR2 & & & & & & & 0.454 \\
\hline Hansen OIR test p-value & & & & & & & 0.15 \\
\hline $\begin{array}{l}\text { Notes: The table displays } \\
\text { change. The dependent va } \\
\text { Table } 1 \text {. Regarding the sy } \\
\text { correction. Robust standar } \\
\text { and } 10 \% \text {. }\end{array}$ & $\begin{array}{l}\text { the fixed e } \\
\text { is } \triangle D E B T \\
\text { GMM re } \\
\text { ors are give }\end{array}$ & $\begin{array}{l}\text { effects and t } \\
\text {. The defini } \\
\text { gressions, } \\
n \text { in parenthe }\end{array}$ & system & $\begin{array}{l}\text { AM regres } \\
\text { pendent } \mathrm{v}\end{array}$ & on results. & $\begin{array}{l}\text { denotes fo } \\
\text { e regressors } \\
\text { with Windm } \\
\text { significanc }\end{array}$ & $\begin{array}{l}\text { the annual } \\
\text { are given in } \\
\text { eijer }(2005) \\
\text { at } 1 \%, 5 \% \text {, }\end{array}$ \\
\hline
\end{tabular}


Table 8: Sovereign Debt Responses to Rating Changes: The Impact of Level of Development

\begin{tabular}{|c|c|c|c|c|c|c|c|}
\hline & \multirow[b]{2}{*}{ (1) } & \multirow[b]{2}{*}{ (2) } & \multicolumn{2}{|c|}{ Fixed Effects } & \multirow[b]{2}{*}{ (5) } & \multirow[b]{2}{*}{ (6) } & \multirow{2}{*}{$\begin{array}{c}\text { System GMM } \\
(7)\end{array}$} \\
\hline & & & (3) & (4) & & & \\
\hline$\triangle D E B T \mathrm{t}-1$ & & & & & & & $\begin{array}{c}0.299 * * * \\
(0.003)\end{array}$ \\
\hline$\triangle R A T I N G \mathrm{t}-1$ & $\begin{array}{c}-1.256^{* *} \\
(0.488)\end{array}$ & $\begin{array}{c}-1.362 * * * \\
(0.481)\end{array}$ & $\begin{array}{c}-1.360 * * * \\
(0.481)\end{array}$ & $\begin{array}{c}-1.981 * * * \\
(0.474)\end{array}$ & $\begin{array}{c}-1.975 * * * \\
(0.474)\end{array}$ & $\begin{array}{c}-1.942 * * * \\
(0.476)\end{array}$ & $\begin{array}{c}-3.230 * * \\
(0.024)\end{array}$ \\
\hline$\triangle R A T I N G \mathrm{t}-1 * D E V$ & $\begin{array}{l}-1.307^{*} \\
(0.684)\end{array}$ & $\begin{array}{l}-1.257^{*} \\
(0.674)\end{array}$ & $\begin{array}{l}-1.257^{*} \\
(0.674)\end{array}$ & $\begin{array}{l}-0.858 \\
(0.656)\end{array}$ & $\begin{array}{l}-0.808 \\
(0.656)\end{array}$ & $\begin{array}{l}-0.852 \\
(0.659)\end{array}$ & $\begin{array}{c}-6.876 * * * \\
(0.002)\end{array}$ \\
\hline$G D P P C$ & & $\begin{array}{c}-0.146 * * * \\
(0.0281)\end{array}$ & $\begin{array}{c}-0.146^{* * * *} \\
(0.0281)\end{array}$ & $\begin{array}{c}-0.157 * * * \\
(0.0273)\end{array}$ & $\begin{array}{c}-0.171 * * * \\
(0.0291)\end{array}$ & $\begin{array}{c}-0.168 * * * \\
(0.0293)\end{array}$ & $\begin{array}{l}-0.116 \\
(0.278)\end{array}$ \\
\hline$\triangle G O V E F F$ & & & $\begin{array}{l}-0.171 \\
(1.526)\end{array}$ & $\begin{array}{l}-0.636 \\
(1.481)\end{array}$ & $\begin{array}{l}-0.590 \\
(1.481)\end{array}$ & $\begin{array}{l}-0.563 \\
(1.481)\end{array}$ & $\begin{array}{r}-11.259 \\
(0.302)\end{array}$ \\
\hline$\Delta I N F$ & & & & $\begin{array}{l}0.329 * * * \\
(0.0448)\end{array}$ & $\begin{array}{c}0.326 * * * \\
(0.0449)\end{array}$ & $\begin{array}{c}0.318 * * * \\
(0.0460)\end{array}$ & $\begin{array}{c}0.312 * * * \\
(0.007)\end{array}$ \\
\hline$\triangle S A V I N G$ & & & & & $\begin{array}{c}0.0759 \\
(0.0562)\end{array}$ & $\begin{array}{c}0.0767 \\
(0.0562)\end{array}$ & $\begin{array}{l}-0.044 \\
(0.892)\end{array}$ \\
\hline$\triangle O P E N N E S S$ & & & & & & $\begin{array}{c}0.0180 \\
(0.0233)\end{array}$ & $\begin{array}{l}-0.080 \\
(0.349)\end{array}$ \\
\hline CONSTANT & $\begin{array}{c}1.853 * * * \\
(0.577)\end{array}$ & $\begin{array}{c}5.470 * * * \\
(0.536)\end{array}$ & $\begin{array}{c}5.472 * * * \\
(0.537)\end{array}$ & $\begin{array}{c}6.851 * * * \\
(0.553)\end{array}$ & $\begin{array}{c}6.969 * * * \\
(0.560)\end{array}$ & $\begin{array}{c}7.172 * * * \\
(0.619)\end{array}$ & $\begin{array}{c}9.290 \\
(0.166)\end{array}$ \\
\hline Observations & 929 & 929 & 929 & 929 & 929 & 929 & 929 \\
\hline Number of countries & 93 & 93 & 93 & 93 & 93 & 93 & 93 \\
\hline R-squared & 0.240 & 0.265 & 0.265 & 0.310 & 0.311 & 0.312 & \\
\hline Number of instruments & & & & & & & 35 \\
\hline AR1 & & & & & & & 0.002 \\
\hline AR2 & & & & & & & 0.819 \\
\hline Hansen OIR test p-value & & & & & & & 0.541 \\
\hline $\begin{array}{l}\text { Notes: The table displa } \\
\text { annual change. The depe } \\
\text { given in Table } 1 . D E V \text { is } \\
\text { group high income: } O E C \\
\text { income, lower middle in } \\
\text { Table 2). Regarding the } \\
\text { correction. Robust standa } \\
5 \% \text {, and } 10 \% \text {. }\end{array}$ & $\begin{array}{l}\text { s both the } \\
\text { lent variabl } \\
\text { dummy va } \\
\text { and high } \\
\text { ome, and } u \\
\text { stem GMN } \\
\text { d errors are }\end{array}$ & $\begin{array}{l}\text { fixed effec } \\
\text { e is } \triangle D E B \\
\text { ariable that } \\
\text { income: no } \\
\text { pper midd } \\
\text { a regressior } \\
\text { given in }\end{array}$ & $\begin{array}{l}\text { and the } \\
\text { The defin } \\
\text { kes } 1 \text { if a } \\
\text { OECD co } \\
\text { income } \\
\text {, we estim } \\
\text { entheses. }\end{array}$ & $\begin{array}{l}\text { stem GN } \\
\text { on of the } \\
\text { ountry is } \\
\text { atries in } t \\
\text { untries in } \\
\text { te two-st } \\
* * *\end{array}$ & $\begin{array}{l}\text { regressio } \\
\text { pendent v } \\
\text { leveloped } \\
\text { "develope } \\
\text { e "develo } \\
\text { system G }\end{array}$ & $\begin{array}{l}\text { results. } \Delta \\
\text { iable and t } \\
\text { untry and } \\
\text { country" } \\
\text { ng countr } \\
\text { M with W }\end{array}$ & $\begin{array}{l}\text { enotes for the } \\
\text { regressors are } \\
\text { otherwise. We } \\
\text { tegory and low } \\
\text { category (see } \\
\text { dmeijer (2005) } \\
\text { ficance at } 1 \% \text {, }\end{array}$ \\
\hline
\end{tabular}




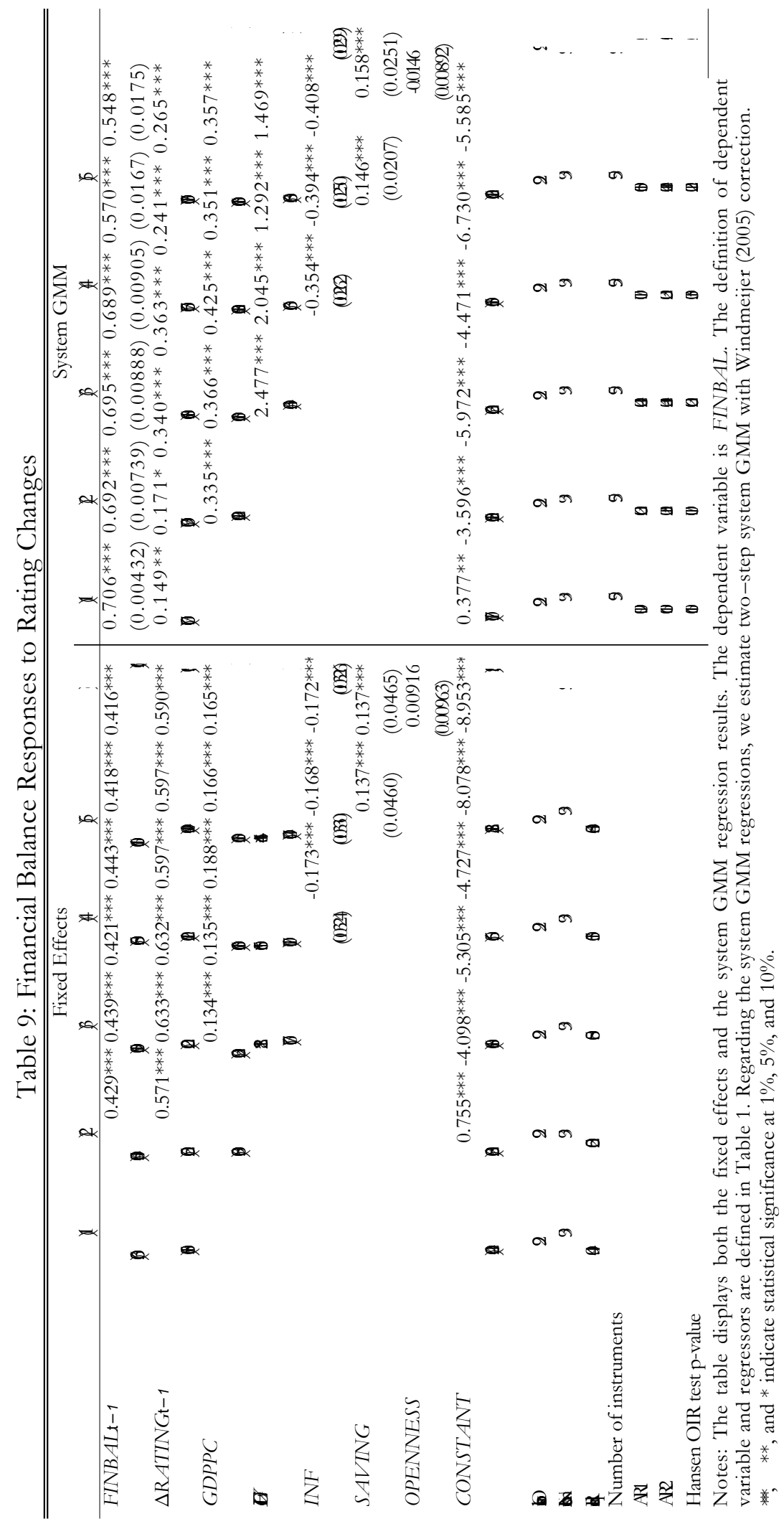


Table 10: Sovereign Debt Responses to Rating Changes: Ordered Probit Model Results

\begin{tabular}{|c|c|c|c|c|c|c|}
\hline & $(1)$ & (2) & (3) & (4) & $(5)$ & (6) \\
\hline $\mathrm{A} R A T I N G \mathrm{t}-1$ & $\begin{array}{c}-0.483 * * * \\
(0.000)\end{array}$ & $\begin{array}{c}-0.444 * * * \\
(0.000)\end{array}$ & $\begin{array}{c}-0.452 * * * \\
(0.000)\end{array}$ & $\begin{array}{c}-0.444 * * * \\
(0.000)\end{array}$ & $\begin{array}{c}-0.453 * * * \\
(0.000)\end{array}$ & $\begin{array}{c}-0.451 * * * \\
(0.000)\end{array}$ \\
\hline$G D P P C$ & & $\begin{array}{c}-0.066^{* * * *} \\
(0.000)\end{array}$ & $\begin{array}{c}-0.066^{* * * *} \\
(0.000)\end{array}$ & $\begin{array}{c}-0.066^{* * * *} \\
(0.000)\end{array}$ & $\begin{array}{c}-0.064 * * * \\
(0.000)\end{array}$ & $\begin{array}{c}-0.064 * * * \\
(0.000)\end{array}$ \\
\hline $\mathrm{A} G O V E F F$ & & & $\begin{array}{c}0.249 \\
(0.479)\end{array}$ & $\begin{array}{c}0.257 \\
(0.467)\end{array}$ & $\begin{array}{c}0.247 \\
(0.484)\end{array}$ & $\begin{array}{c}0.220 \\
(0.533)\end{array}$ \\
\hline $\mathrm{A} I N F$ & & & & $\begin{array}{l}-0.007 \\
(0.548)\end{array}$ & $\begin{array}{l}-0.006 \\
(0.582)\end{array}$ & $\begin{array}{c}0.003 \\
(0.790)\end{array}$ \\
\hline $\mathrm{A} S A V I N G$ & & & & & $\begin{array}{l}-0.012 \\
(0.409)\end{array}$ & $\begin{array}{c}-0.009 \\
(0.523)\end{array}$ \\
\hline AOPENNESS & & & & & & $\begin{array}{c}-0.012 * * \\
(0.016)\end{array}$ \\
\hline Threshold $1(\mu 1)$ & $\begin{array}{c}-0.201 * * * \\
(0.000)\end{array}$ & $\begin{array}{c}-0.802 * * * * \\
(0.000)\end{array}$ & $\begin{array}{c}-0.804 * * * \\
(0.000)\end{array}$ & $\begin{array}{c}-0.799 * * * * \\
(0.000)\end{array}$ & $\begin{array}{c}-0.790 * * * \\
(0.000)\end{array}$ & $\begin{array}{c}-0.796 * * * \\
(0.000)\end{array}$ \\
\hline Threshold $2(\mu 2)$ & $\begin{array}{c}0.220 * * * \\
(0.000)\end{array}$ & $\begin{array}{c}-0.326^{* * * *} \\
(0.000)\end{array}$ & $\begin{array}{c}-0.328 * * * * \\
(0.000)\end{array}$ & $\begin{array}{c}-0.323 * * * * \\
(0.000)\end{array}$ & $\begin{array}{c}-0.313 * * * \\
(0.000)\end{array}$ & $\begin{array}{c}-0.317 * * * * \\
(0.000)\end{array}$ \\
\hline Observations & 929 & 929 & 929 & 929 & 929 & 929 \\
\hline Pseudo-R-squared & 0.0133 & 0.101 & 0.101 & 0.101 & 0.102 & 0.105 \\
\hline Chi-squared & 25.40 & 192.0 & 192.5 & 192.9 & 193.6 & 199.5 \\
\hline Log-likelihood & -939.2 & -855.9 & -855.7 & -855.5 & -855.2 & -852.2 \\
\hline $\begin{array}{l}\text { Notes: The table } \\
\text { explores whether o } \\
\text { variable is an ordir } \\
\text { ment: } 3), 2 \text { with no } 1 \\
\text { for the annual chan } \\
\text { Table } 1 . \text { Robust } \\
\text { significance at } 1 \% \text {, }\end{array}$ & $\begin{array}{l}\text { reports the } \\
\text { not rating } \\
\text { al variable } t \\
\text { scal change } \\
\text { e. The defini } \\
\text {-values are } \\
\% \text {, and } 10 \%\end{array}$ & $\begin{array}{l}\text { results of } \\
\text { changes tri } \\
\text { hat takes th } \\
\text { (no change: } \\
\text { tion of the } \\
\text { given in } \mathrm{p}\end{array}$ & $\begin{array}{l}\text { dered prob } \\
\text { ger change } \\
\text { value of } 3 \\
\text { ), and } 1 \text { wi } \\
\text { ependent va } \\
\text { irentheses. }\end{array}$ & $\begin{array}{l}\text { model } \\
\mathrm{n} \text { fiscal d } \\
\text { with fisca } \\
\text { fiscal (de } \\
\text { able and } \mathrm{t} \\
* * \text {, **, a }\end{array}$ & $\begin{array}{l}\text { uation 3). } \\
\text { cipline. The } \\
\text { mprovemen } \\
\text { ioration: } 1 \text { ) } \\
\text { regressors } \\
* \text { indicat }\end{array}$ & $\begin{array}{l}\text { The model } \\
\text { dependent } \\
\text { (improve- } \\
\text { A denotes } \\
\text { re given in } \\
\text { statistical }\end{array}$ \\
\hline
\end{tabular}

